Available Online at http://journal.unismuh.ac.id/index.php/otoritas

Otoritas : Jurnal Ilmu Pemerintahan, 7 (2), October 2017, 93-99

\title{
The AU/NEPAD Peace and Security Governance in Africa
}

\author{
Isaac Terungwa Terwase ${ }^{1 *}$, Asmat Nizam Abdul Talib², Nfor Eric Siben³, \\ Gloria Samdi Puldu ${ }^{4}$, Olubukola S. Adesina ${ }^{5}$ \\ ${ }^{1}$ Ghazali Shafie Graduate School of Government, Universiti Utara Malaysia, 06010 UUM Sintok, \\ Kedah Darul Aman, Malaysia. \\ ${ }^{2}$ School of International Studies, Universiti Utara Malaysia, 06010 UUM Sintok, \\ Kedah Darul Aman, Malaysia. \\ ${ }^{3}$ Department of Political Science, Faculty of Social Sciences University of Maiduguri, P.M.B. 1069, \\ Bama Road Maiduguri, Borno State, Nigeria \\ ${ }^{4}$ Department of Political Science, Faculty of Social Sciences University of Jos, P.M.B 2084 Jos, \\ Plateau State, Nigeria. \\ ${ }^{5}$ Department of Political Science,Faculty of Social Sciences University of Ibadan, Ibadan, Oyo State, \\ Nigeria .
}

Received: 10 August 2017; Revised: 25 September 2017; Accepted: 21 October 2017

\begin{abstract}
Peace and security sustainability in Africa has become a vital tool for the developmental agenda of the Africa Union. Hence, the continent's conflicting issues and fighting against various groups that emerged from militancy, insurgency and terrorism in Africa is the reason why the peace and security department of the African Union was established for the purpose of solving such problems in order to sustain a peaceful African environment. The main objective of the paper is to draw the role of the African Union (AU) and the New Partnership for Africa's Development (NEPAD) in assisting the African countries in resolving the conflicts which could lead to a state of insecurity. The work made use of qualitative research design through the conduct of interviews as well as the use of other sources such as AU/NEPAD documents, internet sources and journals for the purpose of data collection. The findings revealed that, NEPAD works with the African countries at the country level through the provision of advisory and partnership role on peace and security governance. At the continental level, NEPAD report to the African Union on issues relating to peace and security sustainability which are handled by the AU's department for Peace and Security.
\end{abstract}

Keywords: Peace; Security; Governance; $A U / N E P A D$

How to Cite: Terwase, I. T., Talib, A. N. A., Siben, N. E., Puldu, G. S., \& Adesina, O. S. (2017). The AU/NEPAD Peace and Security Governance in Africa. Otoritas : Jurnal Ilmu Pemerintahan, 7(2), 93-99.

Permalink/DOI: https://doi.org/10.26618/ojip.v7i2.825

${ }^{*}$ Corresponding Author.

E-Mail : isaacterwase@gmail.com

Copyright (C) 2017, Otoritas : Jurnal Ilmu Pemerintahan, ISSN: 2088-3706 (Print), ISSN: 2502-9320 (Online) 
Available Online at http://journal.unismuh.ac.id/index.php/otoritas

Otoritas : Jurnal Ilmu Pemerintahan, 7 (2), October 2017, 94

\section{INTRODUCTION}

The work of Mbaku (2004) assert that the leadership of the five counties namely, Olusegun Obasanjo of Nigeria, Thambo Mbeki of South Africa, Abdoulaye Wade of Senegal, Hosni Mubarak Egypt and Abdelaziz Bouteflika of Algeria were instrumental to the establishment of NEPAD in 2001. It became an initiative that sought for the continent's path to sustainable development with the aim of eradicating poverty, placing Africa alongside with the developed countries from Europe, America, and some of the developed countries in Asia.

NEPAD targets her partnership with the developed countries to invest in Africa. The African countries therefore, need to promote peace and security as a precondition to attract foreign investment. A secured environment is one that can attract both people and development alongside. Development partners of NEPAD are derived from Africa, Asia, Europe, North and South Americans, which serves as both the countries of the North and South (NEPAD, 2014).

In Africa, these development partners are African Development Bank, the African Union, Africa Fertilizer, and Africa Renewal online, Africa Platform for the Development Effectiveness (APDEv), among others. In the UK, it is the responsibility of the Department for International Development (DFID) through the UK government to provide aid to developing countries of the world. The DFID has provided aid to about 90 countries with the aim of eradicating poverty as an international agreement to bring an end to poverty by 2015. In the light of this, DFID serves as a partner with the NEPAD programme initiative in Africa. The Swiss Global Alliance for Improved Nutrition (GAIN) is another partner of NEPAD programme initiative which is aimed at mobilizing public-private partnership as a foundation to engage in the provision of financial and technical support with the view of countering malnutrition through nutritious foods to the affected people (NEPAD, 2014).

China has developed her partnership with the African countries through the establishment of the China Africa Cooperation Forum (CACF). It is geared towards the strengthening of ties with the African continent to expand her economies. China today, has so many investments in African countries to promote the growing need for resources back in China, and to foster her as a global figure in the international market where she is involved in several different businesses. Chinese investment covers oil, agriculture, construction of both structural and industrial buildings, textiles, manganese, copper, uranium, etc. Africa is doing business with so many Chinese companies where the continent's resources are largely untapped (Taylor, 2006).

Acquisition of land in the continent of Africa has become a thing of global investment since the geared up prices of food commodities in 2008. This issue involves the BRICS states as a driving force. Alphabets B-Brazil, R-Russia, I-India, CChina, S-South Africa, forms the BRICS states which are also partnering with NEPAD. One of them is "South Africa" which is the co-founder of African initiative programme NEPAD. Africa has a population that is seen as potential market for global investment. In the area of mobile phone, it is one of the fastest growing economies in telecommunication technology (Bach, 2013).

Asia giant China is thus demanding and utilizing the opportunities in the acquisition of raw materials in the continent. Furthermore, through the exportation opportunities in Africa, U.S and the EU countries are not left out of this discovery rather they are gainfully involved in the acquisition of resources in Africa. This has brought about high increase in both diplomatic ties and official visit to 
the African states. Another partner is that of the Korea-Africa Forum for Economic Cooperation which distinguished herself with the economic action plan during the Seoul meeting of October, 2012. There was a summit held in Equatorial Guinea at the Sipopo city for the African-South American also for the purpose of growing partnership through investment in the continent (Bach, 2013).

In Asia, Turkey-Africa Cooperation opened the doors of diplomatic relations between the African states and Turkey. In 2013 January, a total number of 19 embassies were established within the African continent as part of the diplomatic ties. Thus, there is a fast-growing relation in business engagement as well as issues relating to diplomatic visit partnership (Bach, 2013). Continental integration between the Asian and African regions has promoted the economic and political cooperation among states of both continents. Thus, the India-Africa partnership is already yielding results both in the areas of social-economic and political initiatives that will enhance the ties between India as a nation and African states. As a result, the government of India has invested US1bn to build joint facilities in the line of e-Network for the purpose of integrated satellite (Naidu, 2008).

This will enhance telecommunication for both medicine and education as Pan African e-Network with the African Union. The commitment of the Indian government toward her investment in Africa has made the continent to sign an agreement which will promote African economic integration through India's credit facility of US $\$ 200$ million to NEPAD for the India-Africa Fund. That notwithstanding, an Indian state of Andhra Pradesh signed a letter of intent between the countries of Kenya and Uganda for the purpose of cultivating land in both countries where 500 Indians will be sent to them (Naidu, 2008).

Internet usage is another form of partnership that creates trade relations with countries of the world which bridges the communication technology gap in most countries. However, it is noted that the 54 countries of Africa are not left behind with the connectivity of the internet access especially their capitals. It is a form of trade globalization even in the African continent, for South Africa, its usage of internet facility favorably compares to that of the European countries. It is not up to date in Africa where so many communities lack access to the internet, for the North America and the Europeans, the usage of the internet has promoted medical diagnosis which serves as an instrument for the treatment of diseases. The African continent truly needs such information to serve as a guide to the medical field, especially for the doctors and the medical students for effective professionalism (Sonaike, 2004).

It is therefore, a call for African countries like the US, European countries, Asian countries, to invest in the line of information and communication technology as well as in Research. NEPAD has created that avenue for the continent to partner with the rest of the world in capacity building of social and economic structures. Investment can go a long way when the high level of African resources are yet untapped in many areas such as the natural resources, agriculture, technology and even the human resources that need to be developed. The US through the leadership of President George Bush in July, 2003 paid a historic visit to Africa which promoted the US trade programme with the continent. It was a great step forward to partner and to support the NEPAD programme (Sonaike, 2004).

A call for the support from the US is still today very necessary making use of the designed plan through NEPAD for the development and partnership with Africa. Another issue of concern is that of the end to conflict in Africa states which serves as a challenge to security of life and proper- 
ty, and it has also become a great challenge for both the continent and the global community. Security of humans is very important because, a nation that is at risk of insecurity creates an atmosphere of fear even to the foreigners in such a nation. It makes it difficult for foreign investors to come in and participate in trade and investment. This is the reason why this research work is focused on the issue of security in Africa.

The main objective of the paper is to draw the role of the African Union (AU) and the New Partnership for Africa's Development (NEPAD) in assisting the African countries in solving the conflict challenges which could lead to a state of insecurity.

\section{RESEARCH METHODS}

The work made use of qualitative research design through the conduct of interviews as well as the usage of other sources such as AU/NEPAD documents, internet sources and journals for the purpose of data collection.

\section{RESULT AND DISCUSSION}

\section{AU/NEPAD's Role in Implementing Peace and Security Strategy}

There are various strategies that have been put in place in implementing the peace and security goal of the NEPAD programme initiative which is jointly managed by the NEPAD Agency and the African Union in collaboration with other partners within and outside Africa for the purpose of achieving peace and political stability in African states. Africa Union (2009) the Heads of State and Government which is the highest body of authority both of NEPAD and the AU Assembly has established the African Peace and Security Architecture (APSA) of the African Union during their first Ordinary Session of the African Union Assembly in Durban, South Africa, on the 9th of July 2002.
The Heads of State and Government of the African countries met in Sirte, Libya, on the 28th of February, 2004, where they signed the Solemn Declaration on Defence and Security during their Second Extraordinary Session as a document on peace and security so as to guide the AU/ NEPAD activities in relation to the sector known as Peace and Security. However, the African Peace and Security Architecture is working in collaboration with the Regional Economic Communities (RECs) as well as the Regional Mechanisms (RMs) charged with the responsibility of ensuring Conflict Prevention, Conflict Management and Conflict Resolution, as it has been instructed by the Peace and Security Council of the AU.

For effective work to be done by the African Peace and Security Architecture (APSA), there are elements/characters that are attributed to them which they are known for, such as peace monitoring, peace building at the grass roots level, as well as post-conflict reconstruction and development. These characters are what the Peace and Security Council of the African Union depends on for the sustainability of working relationship with the African Peace and Security Architecture in coordinating their activities. According to NEPAD Agency (2014), some of the bodies to be discussed under the APSA are the instruments that are charged with the responsibility of overseeing peace and security sustainability in African countries such as:

1. The Peace and Security Council(PSC) of the African Union, this is an organ of the African Union that is charged with the responsibility of making decision on issues relating to conflict such as its prevention, management as well as conflict resolution within the African continent. It is therefore, expected to respond to conflict related issues so as to prevent it from turning into crisis or war but to foster unity, promote peace among the people, security and 
political stability within the African continent (AU/NEPAD, 2009).

2. The Continental Early Warning System, this is another organ that is also very vital as issues relating to conflicts are concerned; the Continental Early Warning System (CEWS) is an early warning mechanism that is responsible for promoting peace and security, while supporting the Peace and Security Council of the African Union in preventing conflicts as well as its anticipation. Within the Regional Economic Communities in Africa, there is situation room for CEWS in observing and monitoring situations around the sub-regions as indicated within the member states of the Regional Economic Communities. CEWS therefore, does the analysis based on specific indicators, then with further transmission and communication to the Conflict Management Directorate located at the African Union Commission in Addis Ababa, Ethiopia (AU/NEPAD, 2009). The work of Terwase, AbdulTalib \& Zengeni (2015) opined that the early warning mechanism helps in addressing the issues that may result into conflict which may further lead to a state of war if such issues are not resolved.

3. The Panel of the Wise, this organ constitutes eminent personalities in Africa whose sole responsibility is to intervene at the early stage of conflict as diplomats as well as an advisory body. It is in order to prevent such conflicts from escalating into war which may result in killing of innocent people, burning and bombing of structures, properties etc. it is again charged with the responsibility of advising the African Union on initiatives related to conflict prevention (Africa Union, 2009).

4. The African Standby Force, this organ is designed to engage in conflict intervention situations and promoting the maintenance of peace, security and political stability within the conflicting environments, place, or country. The five regions in Africa namely: North, South, West, East and Central, thus, provides military panels through their regional communities such as NARC, SADC, ECOWAS, EASBRIG and ECCAS respectively. All in a bid to form the African Standby Force as a multidimensional and continental intervention force in Africa (AU/NEPAD, 2009).

5. The Special Fund, Since the NEPAD Agency and the African Union has structured mechanisms that would enable partnership within and outside Africa, the Special Fund is an organ charged with the responsibility of ensuring financial mechanism in place for the support to the African Union in issues related to peace and security in Africa. By so doing, African Union does her contribution to the Fund with six percent from the annual budget, while the Special Fund also receives contribution from international donors in order to secure peace and maintain stability in Africa. Worthy of mention, is the 9th European Development Fund that contributed about 440 million Euros to the Fund (AU/NEPAD, 2009).

\section{The AU/NEPAD Peace and Security Partners}

International and global institutions have gone into partnership with the AU/ NEPAD in order to foster greater collaboration in promoting peace, security as well as political stability in the African continent. By so doing, these institutions include the European Union, the G8, and the United Nations through their organ which is responsible for ensuring peace, security and stability globally known as the UN Security Council. Below are the details of these partnerships with the institutions; 
Available Online at http://journal.unismuh.ac.id/index.php/otoritas

Otoritas : Jurnal Ilmu Pemerintahan, 7 (2), October 2017, 98

1. The European Union, The African Union has gone into partnership with the European Union to foster strategic ways of enhancing and developing such strategies where peace and political stability would reign within the African states. They therefore went into agreements as they established the Joint Africa - EU Strategy in 2007. It was a well-established partnership that evolved a three-year action plan which was focused to develop alongside others priorities of NEPAD as the democratic governance, energy, science and technology, climate change, migration, ICT, mobility, human rights, employment, trade infrastructure, and regional integration (AU/NEPAD, 2009).

Notwithstanding, the most concerned and first among other priority objectives was the partnership in the area of Peace and Security which comprises of areas of support from the European Union to AU/NEPAD were; political dialogue that also deals with mediation; support to the African Peace and Security Architecture; as well as support through funding to the peace operations led by Africa in conflicting countries.

2. The G8, the strategic area where the G8 has supported the African Union through partnership includes communication, logistics, and the civilian components during the peace operations where conflicts need to be managed and resolved. As such, the G8 gave support to the African Union in establishing the African Standby Force (ASF) with a focus in the above mentioned areas. The African Union has led peace support operations in many countries where there were issues of conflicts that led to political instability in such countries like the peace operation in Somalia known as the African Mission in Somalia (AMISOM) as well as African Mission in Sudan (AMIS),
(AU/NEPAD, 2009).

Regarding the crisis in Darfur, Sudan, the African Union led peace support mission later transformed into a combined force made up of the African Union-United Nations Mission in Darfur known as the UNAMID. More so, the AU-UN Mission stands an assurance of reliability in funding the peacekeeping forces and stronger in terms of strategies while on the field to return peace and security in conflicting countries. The Peace Building Fund (PBF) which was established in 2006, received pledges from the G8 to support in funding the PBF. Also in the area of trafficking and proliferation of Small Arms as well as that of Light Weapons, the G8 have not relented in giving support to strengthen on majors and laws in putting an end to such issues.

3. The United Nations, the partnership between the African Union and the United Nations is highly enormous, and has the capacity of the global institution as well as the assembly of Nation-states across the world to support Africa in peace operations. This support is carried out through the backbone of the security organ of the United Nations known as UN-Security council. However, the substantial aspect of the UN to the AU in peacekeeping operations comes from their financial support to such Missions, as well as the strategic building for the peace support mission in conflicting country to return peace, security and political sustainability where conflicts are resolved (Africa Union, 2009).

\section{CONCLUSION}

The search for Africa's peace and security sustainability led to the establishment of the African Union's department for peace and security which is geared towards achieving a sustainable peaceful and secured environment in the continent 
Available Online at http://journal.unismuh.ac.id/index.php/otoritas

Otoritas : Jurnal Ilmu Pemerintahan, 7 (2), October 2017, 99

of Africa. More so, that idea brought into existence the collaboration of the AU and NEPAD to work together towards the actualization of the continent's peaceful coexistence. This work has achieved in pointing out various bodies that partners with the AU/NEPAD in achieving such course. There is the need for the continent of Africa to remain peaceful in order to gear developmental agendas in African countries through partnership which is the main focus of NEPAD as an agency of the African Union.

\section{ACKNOWLEDGEMENT}

The authors are grateful to our respective institutions for deploying all the facilities and support necessary to run the article.

\section{REFERENCES}

Bach, D. C. (2013). Africa in international relations: The frontier as concept and metaphor. South African Journal of International Affairs, 20(1), 1-22.

Mbaku, J. M. (2004). NEPAD and Prospects for Development in Africa. International Studies, 41(4), 387409.

Naidu, S. (2008). India's growing African strategy. Review of African political economy, 35(115), 116-128.

NEPAD Agency, (2014) NEPAD Strategic Plan for the period 2014-2017. retrieved 5 August 2017,from http://www.nepad.org/nepad/ knowledge/doc/3321/nepadstrategic-plan-2014-2017
NEPAD Agency, (2014) What is the NEPAD Planning and Coordinating Agency(NEPAD Agency)?. Retrieved 5 August 2017, from http://www.nepad.org/npca

Sonaike, S. A. (2004). The Internet and the dilemma of Africa's development. Gazette (Leiden, Netherlands), 66 (1), 41-61.

Taylor, I. (2006). China's oil diplomacy in Africa. International affairs, 82(5), 937-959.

Terwase, I. T., Abdul-Talib, A. N., \& Zengeni, K. T. (2015). The Role of ECOWAS on Economic Governance, Peace and Security Perspectives in West Africa. Mediterranean Journal of Social Sciences, 6(3), 257.

Terwase, I. T., Abdul-Talib, A. N., \& Zengeni, K. T. (2015). The Implementation of Peace and Security Programme initiative in Nigeria: The Role of NEPAD. Mediterranean Journal of Social Sciences, 6(3), 54.

Union, A. (2009). The AU/NEPAD African Action Plan 2010-2015: Advancing Regional and Continental Integration in Africa. Addis Ababa: African Union. 